\title{
Immunoblot analysis of immune response to Campylobacter pylori and its clinical associations
}

\author{
H VON WULFFEN, * H J GROTE, * S GATERMANN,* T LÖNING, $\dagger$ B BERGER, \\ C BUHL§
}

From the Institut für *Medizinische Mikrobiologie und Immunologie; †Institut für Pathologie; $\ddagger$ Chirurgische Abteilung für Endoskopie, Universitätskrankenhaus Eppendorf, Hamburg; and the §Abteilung für Innere Medizin, Israelitisches Krankenhaus, Hamburg, Federal Republic of Germany

SUMmaRY Systemic immune response to Campylobacter pylori was detected by the immunoblot technique in serum samples from 200 patients, 129 blood donors, and 96 children. The results of the IgG immunoblot test showed excellent correlation with the detection of $C$ pylori by culture and also with histopathological examination of the antrum, as well as with peptic ulcer disease. An IgA response also occurred and gave results comparable with those of the IgG immunoblot test, although on a quantitatively lower scale. The IgM immunoblots were of no help in the serodiagnosis of $C$ pylori infection. The protein bands that seemed to be the most specific for $C$ pylori and which were consistently observed in patients positive for $C$ pylori were a 110 kilodalton and a 63 kilodalton band on the IgG immunoblot and an 89 kilodalton band on the IgA immunoblot. A 94 kilodalton and a 28 kilodalton band were also included in the evaluation.

While immunoblot analysis may be used effectively for the serodiagnosis of $C$ pylori infection and can distinguish between patients with normal antrum mucosa and those with gastritis, the test does not help to distinguish between those patients with antrum gastritis who subsequently develop peptic ulcers and those who do not.

A correlation between finding Campylobacter pylori in the antrum mucosa and gastritis in addition to peptic lesions was first described by Warren and Marshall ${ }^{12}$ and has since been confirmed in numerous studies throughout the world. ${ }^{3-7}$ Several authors have also shown that patients positive for $C$ pylori develop a systemic as well as local immune response. Different methods have been used, including complement fixation tests, ${ }^{57}$ agglutination tests, ${ }^{5}$ passive haemagglutination assays, ${ }^{8}$ enzyme linked immunosorbent assays, ${ }^{6910}$ and immunoblot techniques. ${ }^{711}$

As we have previously shown ${ }^{7}$ immunoblots of seropositive sera display various band patterns which make interpretation rather difficult. Some bands appear to be quite consistent while others are only rarely found or are not specific. In this study we screened a larger number of sera from patients, blood donors, and children using the immunoblot technique to assess its value in serodiagnosis and to define patterns characteristic of $C$ pylori infection. At the same time we wanted to restrict the number of bands evaluated to facilitate interpretation of the blots.

Accepted for publication 27 January 1988

\section{Material and methods}

Serum samples from 200 patients who had been referred to the medical or surgical endoscopy units of the Universitätskrankenhaus Eppendorf or the medical endoscopy unit of the Israelitisches Krankenhaus Hamburg for upper gastrointestinal endoscopy were evaluated. Antrum biopsy specimens were taken for culture and Gram stain of $C$ pylori and processed as previously described. ${ }^{7}$ In 167 the antrum mucosa was examined histologically. Serum samples from 129 blood donors and 96 children with suspected viral hepatitis (mean age 6.7 years, range 6 months to 15 years) were also included in the study.

\section{SEROLOGY}

Antigen

Three different $C$ pylori isolates which we have described earlier ${ }^{12}$ were used separately as antigen for comparative purposes: CLO 162; CLO 185, which contains a plasmid; and CLO 232, which differs from the other two strains and all our other isolates in that it does not exhibit any detectable urease activity. Strains were maintained at $-80^{\circ} \mathrm{C}$ in tryptic soy broth 
supplemented with $10 \%$ horse serum and $10 \%$ glycerol and were recultured on supplemented blood agar plates for four days as described previously.

\section{SODIUM DODECYL SULPHATE-POLYACR YLAMIDE} GEL ELECTROPHORESIS

Cells were harvested from agar plates by scraping and washed twice in phosphate buffered saline (PBS). Preparation of total cell lysates and sodium dodecyl sulphate-polyacrylamide gel electrophoresis (SDSPAGE) according to the method of $\mathrm{Laemmli}^{13}$ was performed as described previously. ${ }^{7}$ Samples containing about $250 \mu \mathrm{g}$ of protein ${ }^{14}$ were subjected to SDSPAGE using a $0.15 \mathrm{~cm}$ thick slab gel of $12 \%$ acrylamide as running gel and $3.5 \%$ acrylamide as stacking gel. Marker proteins were run alongside.

\section{Immunoblot analysis}

Protein transfer to nitrocellulose was accomplished according to a modification described earlier ${ }^{7}$ of a vacuum blotting procedure. ${ }^{15}$ After the blotting procedure the liberated gel was stained with Coomassie blue ${ }^{16}$ to ensure that the proteins had banded evenly throughout the gel. The nitrocellulose was then washed three times for 10 minutes in a blocking buffer (0.01 M Na $\mathrm{HPO}_{4} / \mathrm{NaH}_{2} \mathrm{PO}_{4}, 0.15 \mathrm{M} \mathrm{NaCl}, \mathrm{pH} \mathrm{7.5}$, $0.5 \%$ Tween $20,0.05 \%$ sodium azide) and was then cut into strips about $3 \mathrm{~mm}$ wide. One strip and the part of the nitrocellulose containing the marker proteins were stained overnight with India ink diluted 1/1000 in blocking buffer. The other strips were each incubated with $2 \mathrm{ml}$ of patient serum diluted $1 / 100$ in blocking buffer overnight with rotation at room temperature. After washing three times for 10 minutes in blocking buffer antibody-antigen reaction was detected as previously described ${ }^{7}$ using alkaline phosphatase conjugated rabbit antihuman IgG, IgA, or IgM (Dianova GmbH, Hamburg, West Germany), each diluted 1/2000 in blocking buffer.

Statistical analysis was done by the $\chi^{2}$ test. $^{17}$

\section{Results}

Fig 1 shows typical examples of $\mathrm{IgG}$ and $\mathrm{IgA}$ immunoblots that were obtained using $C$ pylori strain CLO 185 as antigen. The blot strips were grouped according to the histological appearance of the patients' antrum mucosa; blots from patients with either severe or moderate antrum gastritis displayed a much denser set of reactive protein bands than any of those from patients with normal antrum mucosa.

Correlation of reactivity of individual protein bands with serum samples from patients with antrum gastritis on the one hand and non-reactivity with sera from patients with normal antrum mucosa on the other resulted in the selection of four protein bands for the IgG immunoblot: $110 \mathrm{kD}, 94 \mathrm{kD}, 63 \mathrm{kD}$, and 28 $\mathrm{kD}$. For evaluation of the $\operatorname{IgA}$ immunoblots, the 28 $\mathrm{kD}$ band was omitted and an $89 \mathrm{kD}$ band was included instead. IgM immunoblots are not shown because all 40 sera tested showed only a single band around 60 $\mathrm{kD}$. Longer substrate incubation or dilution of sera $1 /$ 50 instead of $1 / 100$ increased the reactivity of protein bands sharply, but no differences could be observed between serum samples from patients with normal antrum mucosa and those from patients with antrum gastritis. Thus this IgM reactivity was regarded as non-specific and further probing for IgM was stopped.

With a set of 40 patient samples the different $C$ pylori strains CLO 162, CLO 185, and CLO 232 were used as antigen and tested in parallel for comparison of the IgG, IgA, and IgM reactivity patterns. CLO 162 and CLO 185 gave identical results; CLO 232 was discarded as it failed to show a protein band of about $110 \mathrm{kD}$ that was found to be quite characteristic for patients positive for $C$ pylori. In respect of the other bands studied CLO 232 did not differ from the other two strains. As reported elsewhere, ${ }^{12}$ CLO 232 differs from all our other isolates in that it does not hydrolyse urea. CLO 185 was the antigen used in all tests finally evaluated.

Table 1 shows the percentages of reactivity of some

Table 1 Immunoblot reactivity of some characteristic $C$ pylori protein bands, detection of C pylori on culture or Gram stain, and percentages of positive $\operatorname{Ig} G$ as well as $\operatorname{Ig} G+\operatorname{Ig} A$ scores

\begin{tabular}{|c|c|c|c|c|c|c|c|}
\hline Group & $(n=)$ & $\begin{array}{l}\text { Percentage } \\
\text { l10 kD } \\
\text { IgG positive }\end{array}$ & $\begin{array}{l}\text { Percentage } \\
63 \mathrm{kD} \\
\text { IgG positive }\end{array}$ & $\begin{array}{l}\text { Percentage } \\
89 \mathrm{kD} \\
\text { IgA positive }\end{array}$ & $\begin{array}{l}\text { Percentage } \\
\text { IgG score } \\
\geqslant 1.0\end{array}$ & $\begin{array}{l}\text { Percentage } \\
\text { IgG }+\operatorname{Ig} A \\
\text { score } \\
\geqslant 1 \cdot 5\end{array}$ & $\begin{array}{l}\text { Percentage } \\
\text { Cpylori } \\
\text { positive }\end{array}$ \\
\hline $\begin{array}{l}\text { Normal antrum mucosa } \\
\text { Mild antrum gastritis } \\
\text { Moderate antrum gastritis } \\
\text { Severe antrum gastritis } \\
\text { Duodenal ulcer } \\
\text { Gastric ulcer } \\
\text { Gastrectomy } \\
\text { Gastric cancer } \\
\text { Blood donors } \\
\text { Children }\end{array}$ & $\begin{array}{r}37 \\
61 \\
41 \\
29 \\
35 \\
36 \\
12 \\
13 \\
129 \\
96\end{array}$ & $\begin{array}{l}11 \\
47 \\
47 \\
81 \\
59 \\
67 \\
42 \\
46 \\
21 \\
15\end{array}$ & $\begin{array}{l}25 \\
74 \\
81 \\
88 \\
91 \\
81 \\
67 \\
62 \\
22 \\
18\end{array}$ & $\begin{array}{r}8 \\
52 \\
59 \\
88 \\
71 \\
58 \\
58 \\
38 \\
22 \\
7\end{array}$ & $\begin{array}{r}30 \\
83 \\
86 \\
100 \\
94 \\
86 \\
75 \\
69 \\
32 \\
21\end{array}$ & $\begin{array}{r}27 \\
72 \\
83 \\
100 \\
94 \\
86 \\
67 \\
62 \\
32 \\
19\end{array}$ & $\begin{array}{r}8 \\
57 \\
68 \\
88 \\
97 \\
64 \\
64 \\
40\end{array}$ \\
\hline
\end{tabular}


India ink protein stain

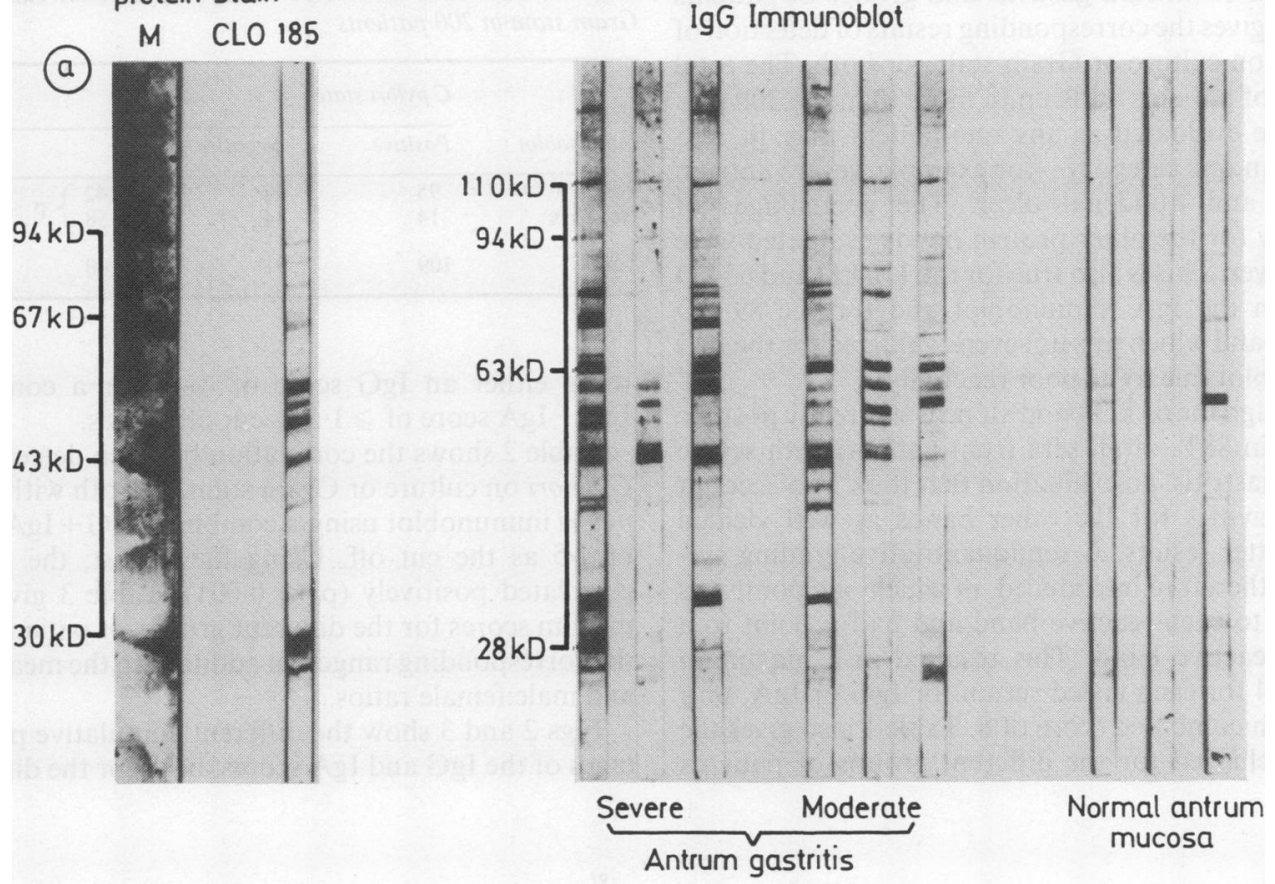

India ink protein stain

M CLO 185

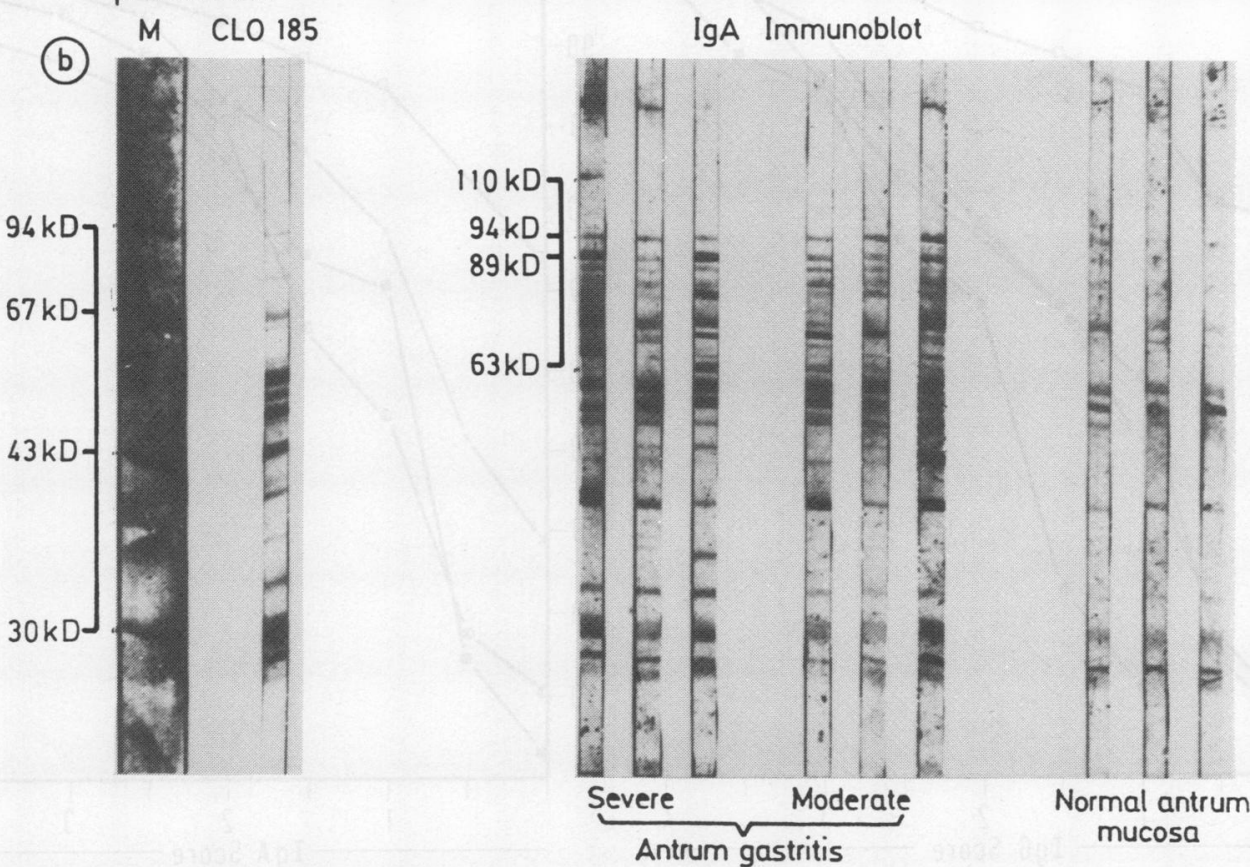

Fig 1 C pylori immunoblots using whole cell lysate of the C pylori strain (CLO 185) as antigen. Blots were incubated with patient sera diluted $1 / 100$ and developed with alkaline phosphatase conjugated anti-human $\operatorname{IgG}(a)$ or $\operatorname{IgA}(b) . M=$ marker proteins. 
of the different protein bands for the different categories of antrum gastritis and groups of patients and also gives the corresponding results of detection of $C$ pylori on culture or Gram stain, or both. The total number of patients adds up to more than the $\mathbf{2 0 0}$ sera that were evaluated as any one patient may fit into more than one category - for example, severe antrum gastritis and duodenal ulcer. The percentages of reactivity for the other protein bands evaluated were much lower. This is also true for the $110 \mathrm{kD}$ and $63 \mathrm{kD}$ bands on the IgA immunoblot and for the $89 \mathrm{kD}$ protein band which was not even evaluated for the IgG immunoblot due to its poor reactivity.

Although the $63 \mathrm{kD}$ band alone was already positive for IgG in $88 \%$ of all sera from patients with severe antrum gastritis, an evaluation that took into account the reactivities for the other bands as well yielded much better results. A semiquantitative grading system was therefore introduced, in which one point was assigned to each reactive band and half a point to a weakly reactive band. This resulted in a maximum score of $\mathbf{4}$ for each tested serum for $\operatorname{IgG}$ or $\operatorname{IgA}$, or a maximum combined score of 8 . Table 1 also gives the results achieved for the different groups of patients

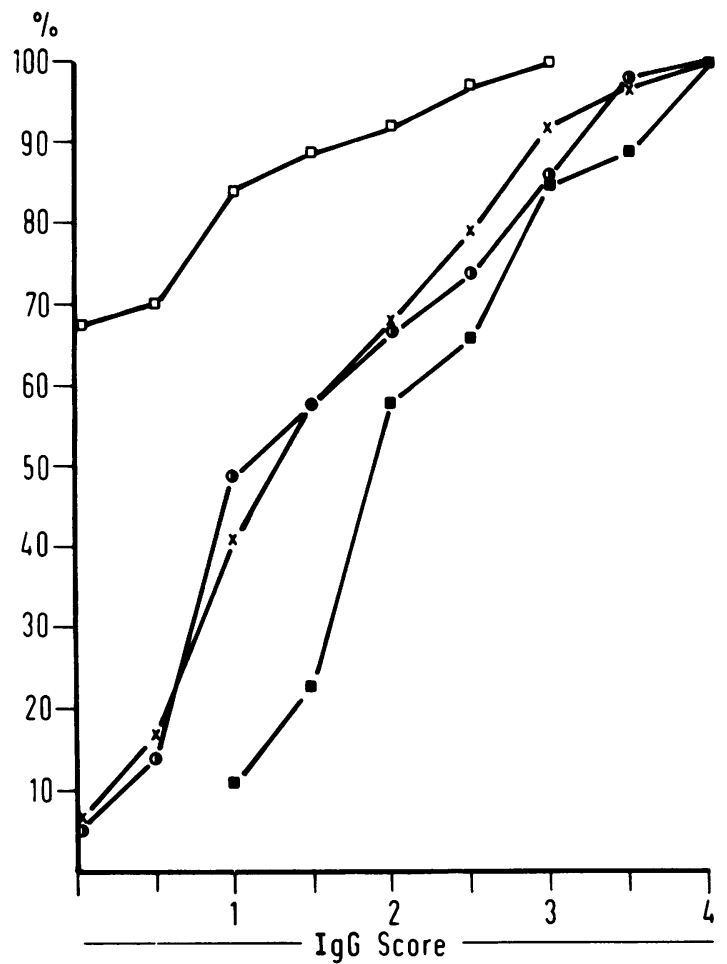

Table 2 Contingency table showing correlation between immunoblot results and detection of $C$ pylori on culture or Gram stain in 200 patients

\begin{tabular}{lllr}
\hline \multirow{4}{*}{ C pylori state } \\
\cline { 2 - 4 } Immunoblot & Positive & Negative & \\
\hline Positive & 95 & 47 & 142 \\
Negative & 14 & 44 & $58\} \mathrm{p}<0.001$ \\
Total & 109 & 91 & 200 \\
\hline
\end{tabular}

using either an IgG score of $\geqslant 1.0$ or a combined IgG + IgA score of $\geqslant 1.5$ as cut off values.

Table 2 shows the correlation between detection of $C$ pylori on culture or Gram stain, or both with the $C$ pylori immunoblot using a combined IgG + IgA score of 1.5 as the cut off. Using the $\chi^{2}$ test, the results correlated positively $(p<0.001)$. Table 3 gives the median scores for the different groups of patients and the corresponding ranges, in addition to the mean ages and male:female ratios.

Figs 2 and 3 show the different cumulative percentages of the IgG and IgA scores, both for the different

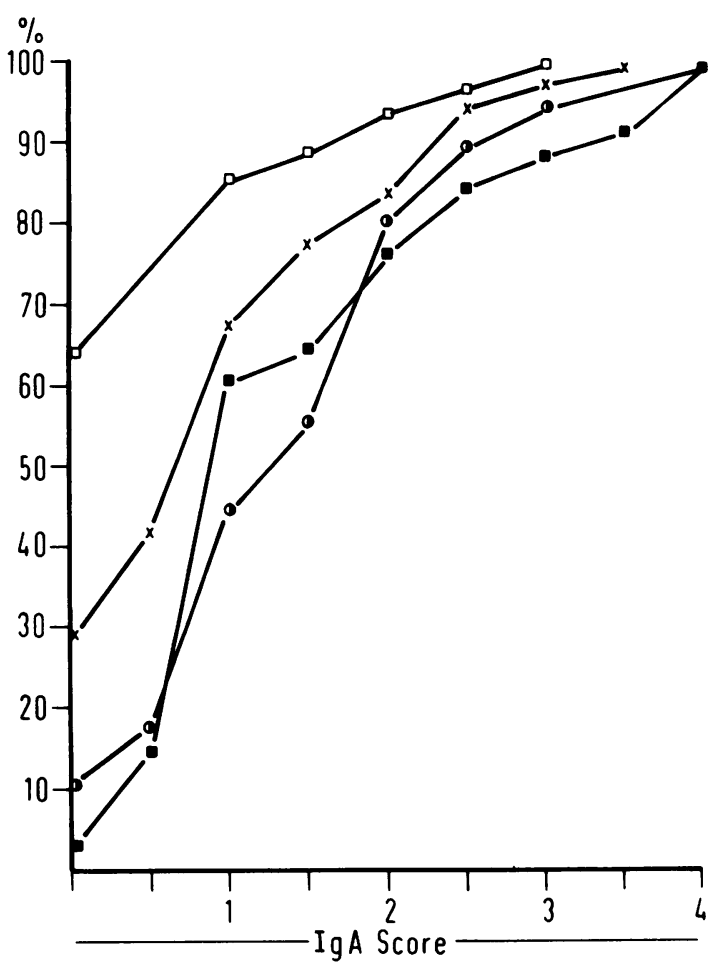

Fig 2 Cumulative percentages of IgG and IgA immunoblot scores for different gastritis groups. $\square-\square$ Normal antrum mucosa; $\times-\times$ mild antrum gastritis; $0-1$ moderate antrum gastritis; $\square$ severe antrum gastritis. 
Table 3 Male:female ratio, mean ages, median IgG + IgA scores and corresponding ranges for various groups of patients, blood donors, and children

\begin{tabular}{|c|c|c|c|c|c|}
\hline Group & $(n=)$ & $\begin{array}{l}\text { Male:female } \\
\text { ratio }\end{array}$ & Mean age & $\begin{array}{l}\text { Median } \\
I g G+I g A \text { score }\end{array}$ & Range \\
\hline $\begin{array}{l}\text { Normal antrum mucosa } \\
\text { Mild antrum gastritis } \\
\text { Moderate antrum gastritis } \\
\text { Severe antrum gastritis } \\
\text { Duodenal ulcer } \\
\text { Gastric ulcer } \\
\text { Gastrectomy } \\
\text { Gastric cancer } \\
\text { Blood donors } \\
\text { Children }\end{array}$ & $\begin{array}{r}37 \\
61 \\
41 \\
29 \\
35 \\
36 \\
12 \\
13 \\
129 \\
96\end{array}$ & $\begin{array}{r}14: 23 \\
25: 36 \\
20: 21 \\
19: 10 \\
25: 10 \\
17: 19 \\
9: 3 \\
8: 5 \\
100: 29 \\
57: 39\end{array}$ & $\begin{array}{r}50 \cdot 3 \\
57 \cdot 6 \\
60 \cdot 7 \\
57 \cdot 2 \\
51 \cdot 4 \\
53 \cdot 9 \\
63 \cdot 3 \\
68 \cdot 1 \\
39 \cdot 3 \\
6 \cdot 7\end{array}$ & $\begin{array}{l}0 \\
2 \cdot 5 \\
3 \cdot 0 \\
3 \cdot 0 \\
3 \cdot 0 \\
4 \cdot 0 \\
2 \cdot 5 \\
2 \cdot 0 \\
0 \\
0\end{array}$ & $\begin{array}{ll}0 & -5 \\
0 & -6 \\
0 \cdot 5 & -6 \cdot 5 \\
1 \cdot 5 & -8 \cdot 0 \\
0 & -6 \\
0 & -7 \cdot 5 \\
0 & -4 \cdot 5 \\
0 & -5 \\
0 & -5 \cdot 5 \\
0 & -4\end{array}$ \\
\hline
\end{tabular}
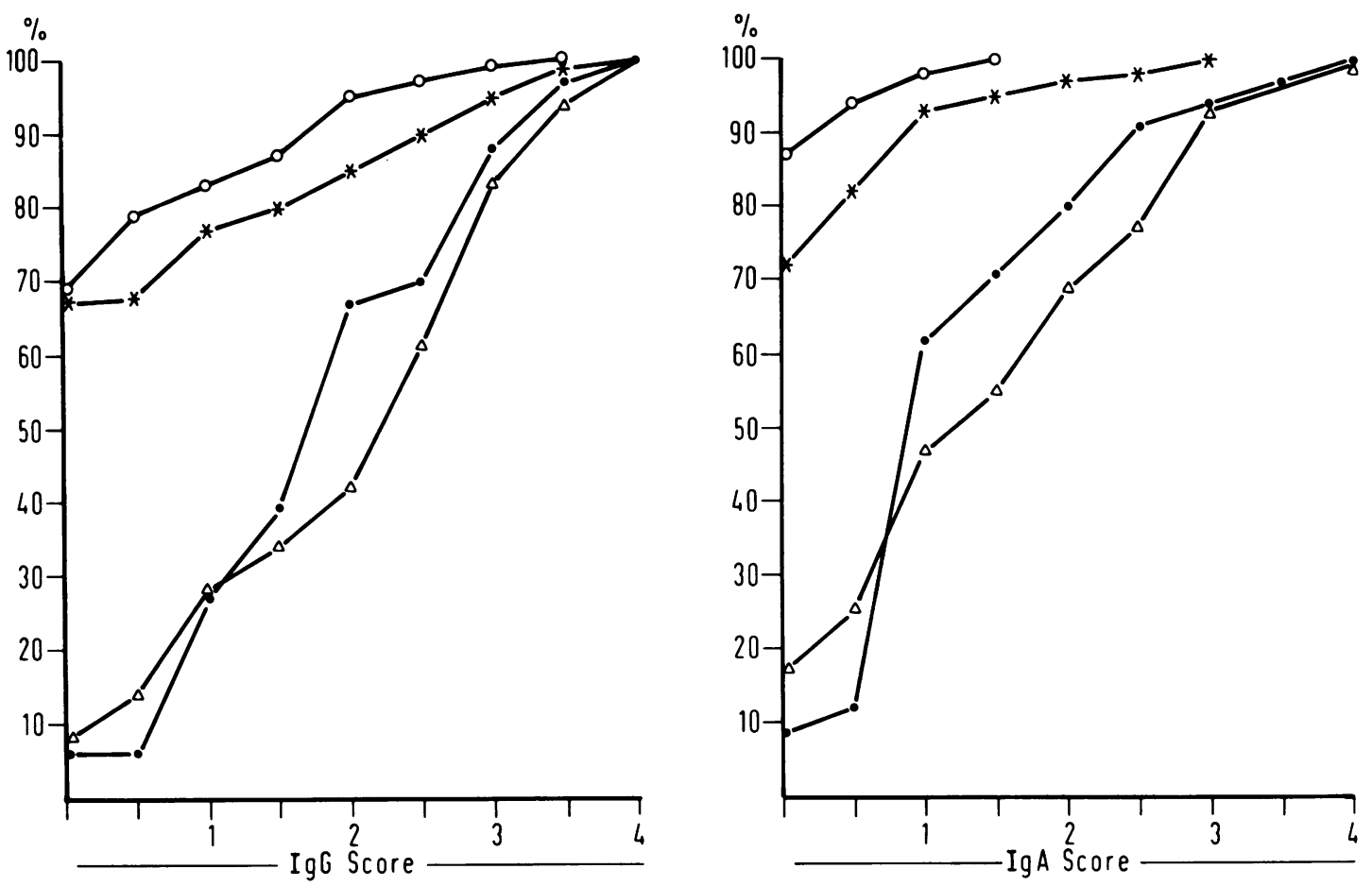

Fig 3 Cumulative percentages of IgG and IgA immunoblot scores for ulcer patients, blood donors, and children.

-D Duodenal ulcer; $\triangle-\triangle$ gastric ulcer; ${ }^{*}$ * $^{*}$ blood donors; $\bigcirc-\bigcirc$ children.

gastritis groups and different patient groups. The distributions of the IgG and IgA scores in the various groups were shown by $\chi^{2}$ test to differ significantly ( $p$ $<0.001$ ). As judged from the curves in fig 2, this difference is accounted for by the low scores in the normal antrum mucosa group as opposed to the much higher scores in the gastritis groups. Where the curves for the different groups of mild, moderate, and severe gastritis run closely parallel and even intertwine, suggests that the distribution of scores within these groups does not vary significantly (fig 2 ). The same applies to the curves for patients with gastric ulcer and duodenal ulcer which are clearly distinct from those of the blood donors and children (fig 3). Again, there is no significant difference in the distribution of the scores between patients with gastric and duodenal ulcers. Fig 3 also clearly shows that sera from children displayed very little IgA reactivity. 


\section{Discussion}

The IgG immunoblot test for $C$ pylori showed a very good correlation with the detection of $C$ pylori and even more so with the histopathological examination of tissue from the antrum. We also detected an IgA response that gave results comparable with those of the IgG immunoblot test, although somewhat on a quantitatively lower scale. The $\operatorname{IgA}$ immunoblot test only rarely yielded information supplementary to that already supplied by the IgG immunoblot. The IgM immunoblots were of no help in the serodiagnosis of $C$ pylori infection. This is not really surprising in a chronic mucosal infection where one would normally expect the immune response to be chiefly of the IgG and $\operatorname{IgA}$ type. Other authors have also predominantly observed an IgG response and, to a lesser degree, an IgA response. ${ }^{69}$ They also did not find testing for IgM to be useful in serodiagnosis. Wyatt et al, investigating the local immune response to $C$ pylori, did, however, ascribe an important role both to the IgA and the IgM response. ${ }^{18}$ Goodwin et al detected only IgG and no IgA or IgM by ELISA. ${ }^{10}$

Protein bands which we found to be highly specific for $C$ pylori were a $110 \mathrm{kD}$ and a $63 \mathrm{kD}$ band for the IgG immunoblot and an $89 \mathrm{kD}$ band for the $\operatorname{IgA}$ immunoblot. Kaldor et al also considered a band around $100 \mathrm{kD}$ to be of special interest in their $C$ pylori immunoblot study." Apel et al also described a band around $120 \mathrm{kD}$ to be highly specific for $C$ pylori (Abstract presented at International Workshop on Campylobacter infections, Göteborg, 1987). Both authors probably were referring to the same protein which we have termed $110 \mathrm{kD}$. The protein band that we called $63 \mathrm{kD}$ probably corresponds to the $60-62 \mathrm{kD}$ protein that Newell described as being specific for $C$ pylori. ${ }^{19}$ She also observed that sera from patients positive for $C$ pylori regularly reacted with this protein.

Other protein bands seem to be less specific or less immunoreactive. Serological cross reactivities of $C$ pylori with other Campylobacter species as well as with other bacteria have been described by some authors. ${ }^{5101119}$ These cross reactivities, however, apparently do not have an important role in the serodiagnosis of $C$ pylori with the serum dilutions generally used in serological tests.

The results for patients with normal antrum mucosa have to allow for the fact that the inflammatory changes may not always be distributed evenly throughout the antrum, and we also saw some patients with normal antrum mucosa who showed both superficial gastritis and $C$ pylori in the body of the stomach.

The results for the blood donors agree with the findings of Langenberg et al, who detected $C$ pylori and antrum gastritis in six of 24 healthy medical students. ${ }^{3}$ These results also correspond to published reports ${ }^{20}$ on the prevalence of chronic antrum gastritis and peptic ulcers in the general population. The results we obtained with the sera from children show that some of these children may actually have had active $C$ pylori infection, and that the hepatitis serology was just part of the laboratory assessment of their abdominal pain. Some authors have recently pointed out that antrum gastritis and even peptic ulcers are not the rare childhood diseases that they are generally considered to be. ${ }^{21-23}$

The results we achieved with the sera from patients with gastric cancer shold be viewed with caution as the number of patients was quite small. This is particularly pertinent in the case of those with intestinal gastric cancer, which has been associated with long standing type B gastritis. ${ }^{24-27}$ The two phenomena, however, might also be conincidental and not casually related. ${ }^{28}$

While our immunoblot test may be used quite effectively to distinguish between patients with normal antrum mucosa and those with antrum gastritis, neither the reactivity of specific bands not the number of reactive bands were significantly correlated with the degree of severity of the antrum gastritis. Nor did the test help to distinguish between those patients with antrum gastritis who develop peptic ulcers and those who do not. Jones et al also did not observe an association between antibody titre and the severity of the antrum gastritis when they used a complement fixation test for $C$ pylori. ${ }^{5}$

What, now, might be the possible clinical applications for such a $C$ pylori serology? Firstly, it might serve to complement or confirm other non-invasive procedures such as the recently described urea breath test, ${ }^{29}$ as a negative $C$ pylori serology makes any association with a possible $C$ pylori aetiology rather improbable. It may also aid diagnosis in patients in whom endoscopy is not feasible or difficult to perform - for example, in children. Furthermore, it might turn out to be a valuable tool in the long term monitoring of therapeutic trials with antimicrobial drugs or bismuth salts.

A further application might be the screening of certain high risk patients. In a preliminary retrospective study we looked at sera from patients before and after renal transplantation. ${ }^{30}$ Some patients who were clearly positive for $C$ pylori on immunoblot analysis (both IgG and IgA) two years before transplantation but had not presented with a previous history of gastritis or peptic ulcers, developed peptic ulcers and even gastrointestinal haemorrhage soon after renal transplantation. Their $C$ pylori immunoblot patterns had not changed. One might speculate, therefore, that chronic $C$ pylori infection predisposed these patients to peptic ulcer disease that did not become overt, however, until further injury to their mucosal defence mechanisms occurred-renal transplantation and 
subsequent immunosuppressive treatment. Early diagnosis and appropriate treatment might have prevented these patients from developing peptic ulcers and gastrointestinal haemorrhage.

Part of this work was presented at the IVth International Workshop on Campylobacter Infections in Göteborg, 1987.

\section{References}

1 Warren JR, Marshall BJ. Unidentified curved bacilli on gastric epithelium in active chronic gastritis. Lancet 1983;i:1273-5.

2 Marshall BJ, Warren JR. Unidentified curved bacilli in the stomach of patients with gastritis and peptic ulcerations. Lancet 1984;i:1311-5.

3 Langenberg W, Tytgat GNJ, Schipper MEI, Rietra PJGM, Zanen HC. Campylobacter like organisms in the stomach of patients and healthy individuals. Lancet 1984;i:1348.

4 McNulty CAM, Watson DM. Spiral bacteria of the gastric antrum. Lancet 1984;i:1068-9.

5 Jones DM, Lessels AM, Eldridge J. Campylobacter like organisms on the gastric mucosa: culture, histological, and serological studies. J Clin Pathol 1984;37:1002-6.

6 Booth L, Holdstock G, MacBride H, et al. Clinical importance of Campylobacter pyloridis and associated serum IgG and IgA antibody responses in patients undergoing upper gastrointestinal endoscopy. J Clin Pathol 1986;39:215-9.

7 von Wulffen H, Heesemann J, Bützow GH, Löning T, Laufs R. Detection of Campylobacter pyloridis in patients with antrum gastritis and peptic ulcers by culture, complement fixation test, and immunoblot. J Clin Microbiol 1986;24:716-20.

8 Marshall BJ, McGechie DB, Francis GJ, Utley PG. Pyloric campylobacter serology. Lancet 1984;ii:281.

9 Rathbone BJ, Wyatt JI, Worsley BW, et al. Systemic and local antibody responses to gastric Campylobacter pyloridis in nonulcer dyspepsia. Gut 1986;27:642-7.

10 Goodwin CS, Blincow E, Peterson G, et al. Enzyme-linked immunosorbent assay for Campylobacter pyloridis: correlation with presence of $\mathrm{C}$ pyloridis in the gastric mucosa. $J$ Infect Dis 1987;155:488-94.

11 Kaldor J, Tee W, Nicolacopolous C, Demirtzoglou K, Noonan D, Dwyer B. Immunoblot confirmation of immune response to Campylobacter pyloridis in patients with duodenal ulcers. Med $J$ Aust 1986;145:133-5.

12 von Wulffen $\mathbf{H}$. Low degree of relatedness between Campylobacter pyloridis and enteropathogenic Campylobacter species as revealed by DNA-DNA blot hybridization and immunoblot studies. FEMS Lett 1987;42:129-33.

13 Laemmli UK. Cleavage of structural proteins during the assembly of the head of bacteriophage T4. Nature 1970;227:680-5.

14 Markwell MAK, Haar SM, Bieber LL, Tolbert NE. A modification of the Lowry procedure to simplify protein determinations in membrane and lipoprotein samples. Anal Biochem 1978;87:206-10.

15 Peferoen M, Haybrechts R, de Loof A. Vacuum-blotting: a new simple and efficient transfer of proteins from sodium dodecyl sulfate-polyacrylamide gels to nitrocellulose. FEBS Lett 1982;145:369-72.

16 Heesemann J, Algermissen B, Laufs R. Genetically manipulated virulence of Yersinia enterocolitica. Infect Immun 1984;46: 105-10.

17 Armitage P. Statistical methods in medical research. Oxford: Blackwell Scientific Publications, 1971.

18 Wyatt JI, Rathbone BJ, Heatley RV. Local immune response to gastric Campylobacter in non-ulcer dyspepsia. J Clin Pathol 1986;39:863-70.

19 Newell DG. Identification of the outer membrane proteins of Campylobacter pyloridis and antigenic cross-reactivity between C. pyloridis and C. jejuni. J Gen Microbiol 1987;133:163-70.

20 Jorde R, Burhol PG. Review: Asymptomatic peptic ulcer disease. Scand J Gastroenterol 1987;22:129-34.

21 Czinn SJ, Dahms BB, Jacobs GH, Kaplan B, Rothstein FC. Campylobacter-like organisms in association with gastritis in children. J Pediatr 1986;109:80-3.

22 Drumm B, Sherman P, Cutz E, Karmali M. Association of Campylobacter pyloridis on the gastric mucosa with antral gastritis in children. $N$ Engl J Med 1987;316:1557-61.

23 Hill R, Peermann J, Worthy P, Caruso V, Goodwin S, Blincow E. Campylobacter pyloridis and gastritis in children. Lancet 1986;i:387.

24 Heilmann KL, Cuello C, Hoepker WW. Die Gastritis als Krebsrisikoerkrankung-Epidemiologisch-morphologische Untersuchungen. Leber Magen Darm 1982;12:115-21.

25 Iida F, Kusuma J. Gastric carcinoma and intestinal metaplasia. Cancer 1982;50:2854-8.

26 Nardelli J, Bara J, Rosa B, Burtin P. Intestinal metaplasia and carcinomas of the human stomach. An immunohistological study. J Histochem Cytochem 1983;31:366-75.

27 Siurala M, Kivilaakso E, Sipponen P. Gastritis. In: Demling L, ed. Klinische Gastroenterologie. Vol 1. Stuttgart: Thieme, 1984: 321-37.

28 Hattori T. Development of adenocarcinomas in the stomach. Cancer 1986;57:1528-34.

29 Graham DY, Evans DJ, Alpert LC, et al. Campylobacter pylori detected noninvasively by the ${ }^{13} \mathrm{C}$-urea breath test. Lancet 1987;i:1174-7.

30 von Wulffen H, Grote HJ, Krämer-Hansen H. Serological screening for Campylobacter pylori in candidates for renal transplantation. Lancet 1987; i:1140-1.

Requests for reprints to: Dr. med. H. von Wulffen, Institut für Medizinische Mikrobiologie und Immunologie, Universitätskrankenhaus Eppendorf, Martinistrasse 52, D-2000 Hamburg 20, F.R.G. 